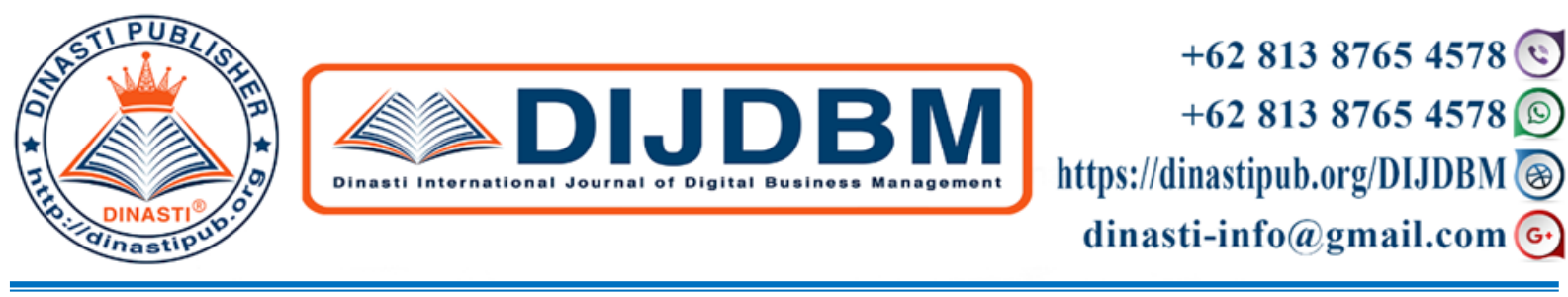

\title{
PLANNING BUSINESS MODEL CANVAS WITH SWOT METHOD AT XYZ INSTITUTE
}

\section{RA. Iis Suci Nur Indah S K ${ }^{\mathbf{1}}$}

1) Mercu Buana University, Jakarta, Indonesia

ARTICLE INFORMATION

Received: $25^{\text {th }}$ May 2020

Revised: $20^{\text {th }}$ June 2020

Issued: $19^{\text {th }}$ August 2020

Corresponding author: First

Author

Email:

radenayuiisindah@gmail.com

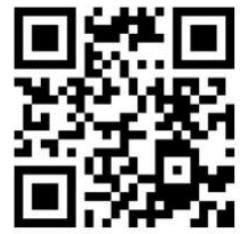

DOI:10.31933/DIJDBM
Abstract: The background of this research is that every company must be able to make a new strategy that is right to be able to compete in the present and also in the future with other similar companies. The XYZ Institute is an institution that was established and operating since 1998. Based on data obtained in the last 4 years, the number of students enrolled at the XYZ Institute has increased and also declined erratically. Allegedly because the marketing planning segment is not yet right. The focus of this study is to identify elements within the Institute that deal directly with customers, in this case students. This research uses a descriptive qualitative approach, the type of research is a case study. Data collection is done by interview, observation, documentation, and questionnaire. Withusing the Businees Model Canvas (BMC) approach proposed by Osterwalder and Pigneur (2010). After the researcher identifies 9 elements in BMC, the researcher then conducts a SWOT analysis. The link between SWOT analysis and Business Model Canvas in this study is that SWOT can help identify strengths, weaknesses, opportunities and threats faced by companies in the process of implementing nine elements of BMC. The results of the BMC identification which were then analyzed through the BMC matrix showed that the XYZ Institute needs to change the pattern of marketing business strategies they currently have and make as many connections as possible with high school / vocational / STM schools throughout Jakarta specifically.

Keywords: Strategic Management, BusinessCanvas Model, SWOT Analysis, SWOT Method

\section{INTRODUCTION}

The Education Sector in Indonesia is increasing every year with the increasing desire of the community to continue their education programs to tertiary institutions. According to 
Wikipedia College is an optional final stage in formal education. Usually delivered in the form of universities, academies, colleges, seminaries, music schools, and institutes of technology college students called students, while the teaching staff is called lecturers. BPS in 2019 has recorded 7.5 million people entering tertiary institutions in 2018 consisting of 4.5 million students from private tertiary institutions (PTS) and 2.5 million from State Universities (PTN) which means $32,9 \%$ of the Indonesian population. This data shows an increase from 2017 which was only 6.9 million people.

Based on the graph obtained from the website of the forlap Dikti which houses all tertiary education in Indonesia shows how many tertiary institutions are in DKI Jakarta, which is around 402 universities that have been officially registered and have accreditation at this time while only 29 institutions for the Institute.

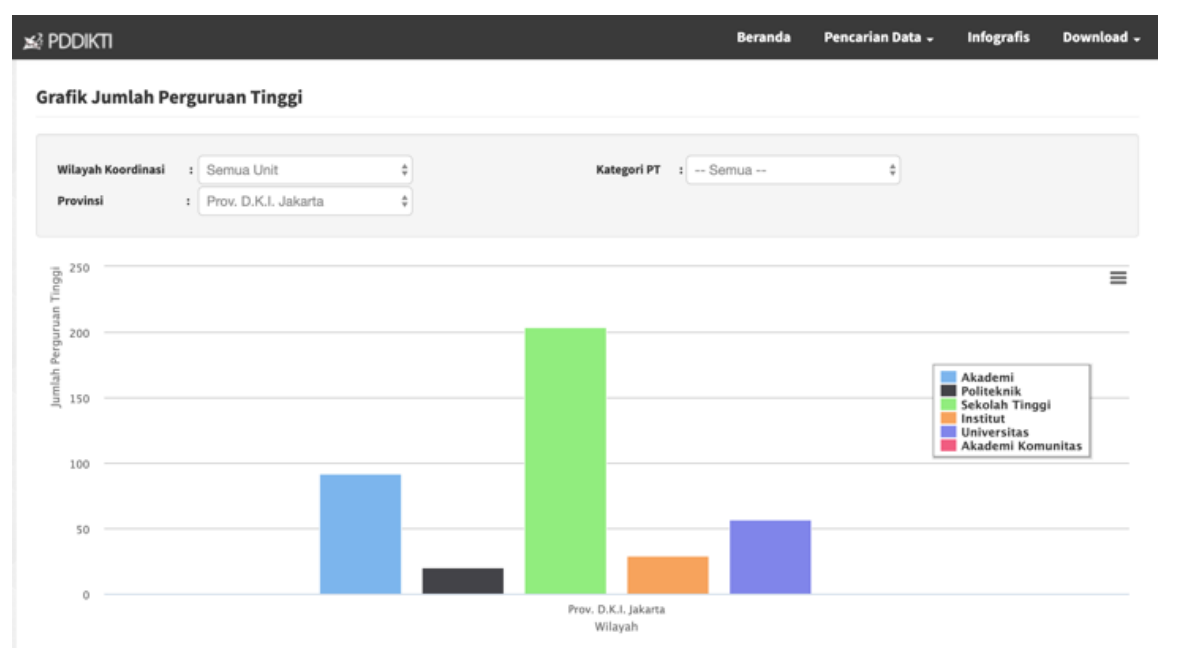

\section{Graph 1. Total of University in Indonesia}

Source: https://forlap.ristekdikti.go.id/perguruantinggi/homegraphpt

One's interest to enter tertiary education has a lot of background according to research conducted by Wiwik Sudarwati and Desta Erlando Tikwalau (2014) as much as $87.172 \%$ is due to economic conditions and 5.789\% reasons for choosing tertiary factors from 5 factors used as a reference as reasons choosing private tertiary institutions, varying education costs that have groups and waves owned by each institution are taken into consideration by prospective students but there are also institutes such as the XYZ Institute which have a tuition fee system by setting flat fees to completion and having one-time development costs during lectures apart from tuition fees usually prospective students have the desire to choose faculties such as Engineering,Medicine and Economics are the most sought after by prospective students in each Educational Institution, the Faculty of Engineering at the XYZ Institute, for example, which has several majors such as Mechanical Engineering, Electrical \& Electronic Engineering, Civil Engineering and the latest Informatics Engineering whose graduates are 
expected to work in several state companies and start ups engaged in the field of electrical engineering and telecommunications engineering the selection of majors which are also seen in terms of accreditation that has been owned by each tertiary institution and selected majors that can also show the credibility of tertiary institutions As a country that upholds education such as which has been stated in the opening of the 1945 Constitution,Indonesia should be able to prioritize education but in reality in the Education Index survey conducted by Human Development Repost (2017) Indonesia is in seventh position in Southeast Asia with a value of $0.622 \%$ the best value obtained by Singapore with a value of $0.832 \%$ the figure is calculated using Mean Years of Schooling and Expected Years of Schooling from 10 Countries in Southeast Asia which means that public knowledge about the importance of education is still not able to reach the maximum level as well as the government in educating the public about education.

The structure and control of transactions designed to create and deliver value through the utilization of business unity that can create value through the utilization of business excellence that can be achieved through driving value, renewable, locked and efficient. To respond to the opportunities and challenges that occur the business development model used is the canvas business model, Osterwalder and Pigneur (2010) offer a canvas that is Business Model Canvas (BMC) also used to visualize ideas, logic of thinking, or frameworks of designers to facilitate the perpetrators and business decision makers including designing, evaluating, managing the business model. BMC, which has many key segments to explore the strengths and weaknesses of the institution itself, the use of the canvas business model also uses a swot approach to improve quality and what things need to be improved. Freddy Rangkuti (2014: 19) explains that the SWOT analysis is the systematic identification of various factors to formulate a company's strategy. This analysis is based on logic that can maximize strengths and opportunities, but simultaneously minimize weaknesses (Weaknesses) and threats (Threats). According to Osterwalder and Yves Pigneur (2012: 216) SWOT analysis in the canvas business model provides four perspectives (strengths, weaknesses, opportunities, and threats) to assess the elements of a business model.

Based on the explanation that has been conveyed, it seems that the role of the XYZ Institute requires efforts to better socialize the vision and mission of higher education in a way that is easily understood and carried out using business models that are already widely used but effective

\section{LITERATURE REVIEW}

\section{Understanding Business Models As Methods}

Wheelen \& Hunger defines the business model as a method used by companies to make money in the business environment in which companies operate. The Rappa gives a similar definition, which is the method used by the company to run its business that makes the company survive. The conclusion according to the definition, business model is a method or way of creating value. 
Meanwhile, if this strategy is emphasized, then this business model is explained as a description of the relationship between excellence and the resources of the company, as well as the activities undertaken to acquire and create value, which makes the company able to generate profits. However, we should consider the above definition as a summary of various understandings and writings about the business model that is linked to strategy.

\section{Business Model Components}

With the business model used by the organization, business will produce value. Therefore, a business model should include factors including:

1. Who is served

2. What is offered

3. How to produce a product

4. How to make a profit

5. how companies differentiate themselves strategically from competitors

The latter factor makes it possible for companies that do business in the same industry to have the same business model. Thus, competition becomes extraordinarily intense, which of course results in companies being trapped in unreasonable competition. In accordance with the strategy of W. Chan Kim and Renee Mauborgne in his book entitled Blue Ocean Strategy, companies that are trapped in bloody competition will be in the red ocean. In this position, the company bears a heavy burden because its performance is no longer efficient and competition is very tight.

\section{The Four-Box Business Model}

Johnson in 2000 mentioned a business model called the four-box business model. This four-box business model consists of:

1. Consumer value position

Is what is offered by the company to consumers, so consumers can solve their main problems more effectively, easily, comfortably, or cheaper. This component of consumer value also includes the way companies submit their offers to consumers so that consumers are more satisfied. The position of consumer value is what decides consumers will determine which company to choose.

2. Key Resources

Is the uniqueness of people, technology, raw materials, equipment, machinery, facilities, funding, and brands needed to produce a proportion of value for consumers. The most strategic resources are those that are scarce, difficult to replace, difficult to imitate, and valuable.

3. Key processes

Is a way for companies to produce and deliver a proportion of value to consumers, in a way that is guaranteed to be sustainable, easy to manage, and can be repeated.

4. Profit Formula 
Is the final part of the four-box business model. The profit formula emphasizes value for the company. This profit formula includes aspects of price, volume, profit, direct costs, indirect costs, and speed of resources. In the profit formula the price level offered needs to be designed.

\section{Business Model Canvas}

Osterwalder and Pigneur offered a method that would later be called the canvas business model as a piece of paper for a writer, a canvas for a painter, or a computer screen for a designer. The canvas they created is used to visualize ideas, logical thinking, or frameworks of designers. In this case the designers are business people, entrepreneurs, and managers in business organizations and non-profit organizations.

The business model describes rationally about how an organization (both profit and non-profit) creates, communicates, and finds important values for customers.

Business Model Canvas (BMC) is the same language to describe, visualize, assess, and change business models (Osterwalder and Pigneur, 2012: 12). To understand how to work in large and complex organizations need a picture that can help change the assumptions that can not be spoken into clear information so that it can be effectively communicated (Clark et al, 2012: 31).

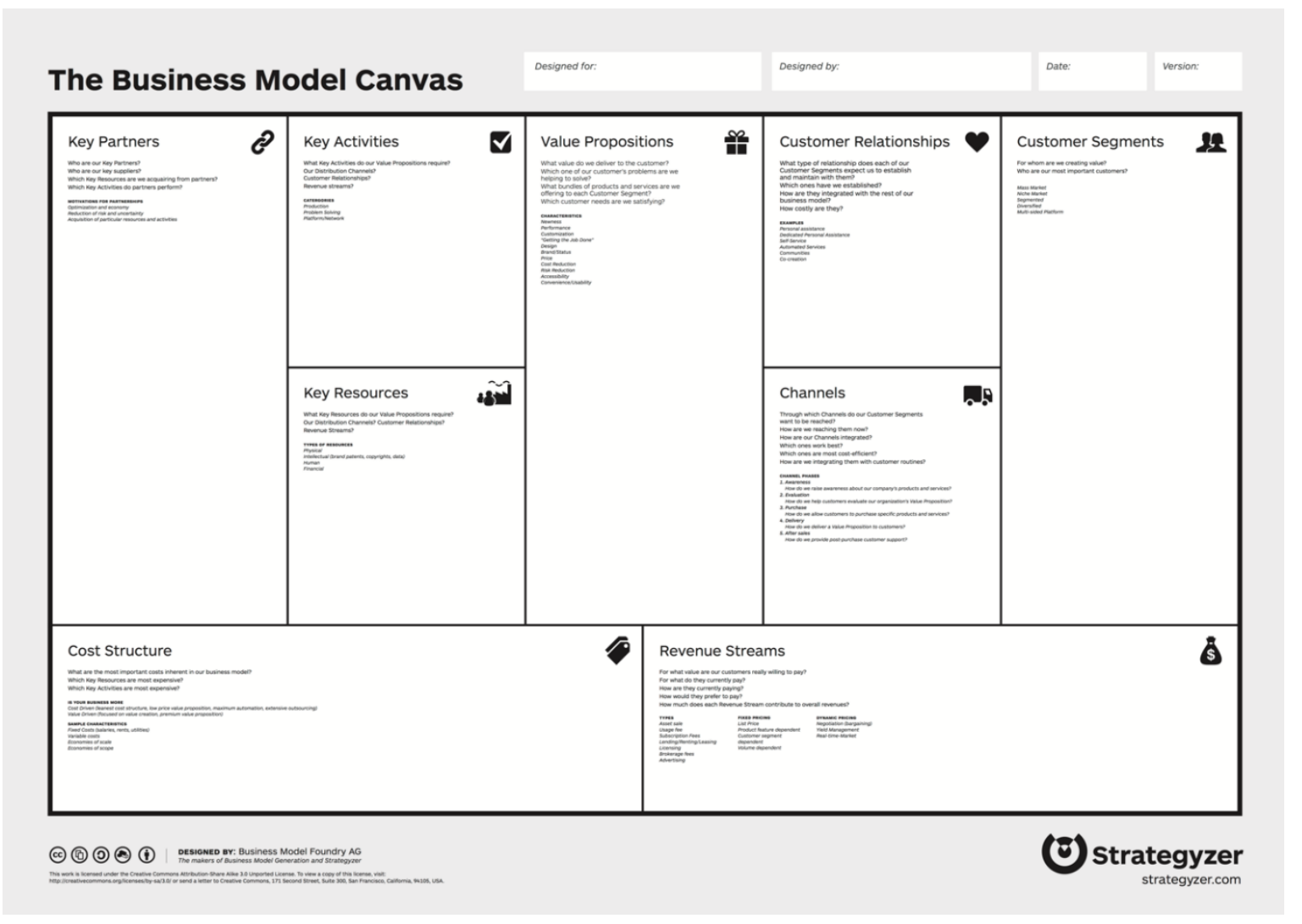

Figure 1: Business Model Canvas 
There are nine elements in the canvas business model, including:

1. Key Partners (Key Partnership)

Key partners are partners in operating the organization. Organizations need this partnership for a variety of purposes which generally are savings due to not achieving economies of scale and reducing risks in obtaining resources.

2. Key Activities

Is an activity that determines the success of a business model. This activity plays an important role in realizing the proportion of values. Not all activities need to be categorized as key resources that truly support the organization's success in delivering a proportion of its value to customers.

3. Key Resources

Describe the most important assets that determine the successful operation of the business model. These valuable assets enable the organization to realize the proportion of value promised to customers well. These resources can be in the form of physical, intellectual and human resources. Of these four sources, intellectual resources are very important assets because they are difficult to imitate.

4. Value Proposition

It is a uniqueness that determines whether a product or service is worth choosing by the customer. Proportion of value offers to solve customer problems or fulfill customer desires as much as possible. The uniqueness that is highlighted must be something different compared to that of competitors, as well as something that is really desired by the customer segment.

5. Customer Relationship

Relationship building aims to get new customers, keep old customers, and offer old or new products and services to old customers.

6. Channels (Channels)

A channel is an element that states how an organization communicates with its customer segments and conveys a proportion of its value. Channels include ways to increase awareness, make it easy for customers to provide products or services, deliver products or services, and provide after-sales service.

7. Customer Segments (Customer Segments)

Is a certain party that uses the services or products of the organization in accordance with their needs. It is they who contribute in providing income for the organization. Generally, customers are those who pay directly for the services or goods they buy.

8. Cost Structure

Describe all costs that arise after the operation of this business model. The cost structure is influenced by the strategy chosen by the company, whether it prioritizes low costs or special benefits.

9. Reveneu Stream

Describe how the organization earns money from each customer segment. The flow of funds is what allows the organization to stay alive. 


\section{Definition of SWOT Analysis}

In the Big Indonesian Dictionary, the word analysis can be interpreted as a process of solving problems or problems that begin with the assumption of its truth and can also be interpreted as a study of an event (actions, results of thought and so on) to find out the actual situation. The word SWOT is short for Strengths (Strengths), Weaknesses (Weaknesses), Opportunities (Opportunities), and Treaths (Challenges). Strengths and weaknesses are derived from the internal environment while opportunities and obstacles come from the external environment.

SWOT analysis is a method of analysis to identify internal and external factors of the organization. Internal factors are strengths and weaknesses, while external factors are opportunities and threats. From this it can be understood that SWOT analysis is a strategy to solve problems in the world of education by looking at the strengths and weaknesses of the internal environment and the opportunities and obstacles of the external environment.

The explanation of the four factors is as follows:

1) Strength Factors (Strengths)

Stretchers(strength) is a positive internal condition that provides competitive advantages in facing competition for educational institutions. These strengths are also the advantages of the institution - both in terms of its resources and efforts that have been made - which are better than competitors. This power then becomes the key difference between one educational institution and another. From this, it can be understood that the strength factors in an educational institution are the specific competence or excellence of the educational institution, giving rise to a plus in the view of the community.

This can be seen if an educational institution has an advantage that makes the community choose the educational institution for their children, the skills of the students' skills and in addition the output or results of the graduates of the educational institution become a mainstay and can continue their level of education better and other advantages that make it superior to other educational institutions.

2) Weaknesses

Weakness(weakness) is an internal negative factor that can hamper the company's ability to achieve its mission, goals and objectives. Lack of capital, unskilled workers, inability to master technology, and poor distribution channels are examples of weaknesses that the company may have. In other words, weaknesses are shortcomings owned by an institution, so the education institution must know how to determine policies to minimize weaknesses so that they become strengths and not become obstacles to the future.

3) Opportunities

Opportunity(opportunity) is a present or future condition that benefits the 
institution. Opportunities are positive external options that can be utilized by the company to achieve its mission, goals and objectives. Basically, the number of potential opportunities is so unlimited that business owners need to analyze the factors that most influence the company. In this case, it is important for companies to focus on the most promising opportunities, which are in line with the company's strengths and core competencies.

When identifying opportunities, business owners must carefully consider the potential for new markets. Here are the things that need to be observed:

a) Do competitors ignore the potential or niche market?

b) Are there other events or methods that are better for reaching or attracting customers?

c) Can the company develop new products that are more innovative, which can provide more value to customers?

d) What are the future opportunities created by industry-style trends that the company is currently engaged in?

e) Important trends among students

f) educational services that have not yet received attention.

g) Relations with the community.

h) Adequate and supportive environment.

i) Community needs are in accordance with the vision, mission and goals of education.

Opportunities arise from various factors that are beyond the company's control. Continual identification of the opportunities that exist and that are in accordance with the strengths and core competencies of the company, then take a leap or extreme action to overtake competitors is the key to the company's success.

4) Challenge Factors (Treaths)

Treats(challenges) are negative external forces that can hinder or hamper the company's ability to achieve its mission, goals and objectives. Threats to companies can take various forms, such as the entry of new competitors in existing markets, government regulations in business, economic recession, high bank interest rates, technological advances that make company products obsolete, and so on. Even though the company cannot control the threat, the company must be able to prepare its best plan to protect it from possible threats that arise. Companies with the right strategy will be able to face the fierce business competition.

Identifying the strengths and weaknesses of the company helps business owners to understand the company's strengths. The strengths must come from the company's core competencies, in order to continue to be competitive in the world of intense business competition. The key in developing a successful business strategy is to use the 
strengths that the company has as a foundation for dealing with competitors.

In identifying the company's strengths and weaknesses as a foundation to face competitors. In identifying the strengths and weaknesses of the company, the business owner can make a list that includes both positive and negative sides of the company.

Opportunities and threats are the result of interactions of fish, trends, and activities that are beyond the direct control of the company. These external pressures (political and regulatory, technological, economic, social, and demographic) have a direct impact on the market behavior in which the company's business operates, the behavior of competitors, and also the behavior of customers.

The combination of strengths, weaknesses, opportunities and threats analysis (SWOT analysis) is part of the company's strategic plan. With this analysis, business owners can see objectively about the company and the environment in which the company and the environment in which the company operates, and help companies overcome the fundamental issues to achieve competitive advantage and success of the company in the future.

\section{SWOT Analysis Function}

According to Ferrel and Harline (2005), the function of the Swot analysis is to obtain information from a situation analysis and separate it into internal issues (strengths and weaknesses) and external issues (opportunities and threats).

SWOT analysis This will explain whether the information indicates something that will help the company achieve its objectives or give an indication that there are obstacles that must be faced or minimized for the desired income.

SWOT analysiscan be used in various ways to improve analysis in the strategy setting effort. Generally, what is often used is a systematic framework / guide in discussions to discuss basic alternative conditions that may be considered by the company.

\section{Limitations of SWOT Analysis}

The limitations when conducting a SWOT analysis are as follows:

1. This analysis can undermine internal forces and minimize external threats

2. This analysis can be static and risky when we ignore the ever-changing circumstances

3. This analysis can suppress one strength or element of a company's strategy 


\section{RESEARCH METHOD}

This study uses descriptive qualitative methods, namely the type of research that has the aim to provide an explanation of the phenomena that occur at the present time (Umar, 2005). The type and source of data used are qualitative, namely personal documents, field notes, respondents' words and actions as well as supporting documents. Qualitative data serves to determine the quality of the object under study. The data needed in this study are primary data and secondary data. Primary data is research data obtained from the first data source or research subject while secondary data is data obtained from supporting data sources. This study uses source triangulation by comparing a person's perspective with various people's opinions or views (Moleong, 2012).

This study also uses the Businees Model Canvas (BMC) approach proposed by Osterwalder and Pigneur (2010). After the researcher identifies 9 elements in BMC, the researcher then conducts a SWOT analysis. The link between SWOT analysis and Business Model Canvas in this study is that SWOT can help identify strengths, weaknesses, opportunities and threats faced by companies in the process of implementing nine elements of BMC. This combination allows focused assessment based on evaluating the company's capabilities and possibilities company development in the future.

\begin{tabular}{|c|c|c|c|c|c|c|c|}
\hline \multicolumn{2}{|r|}{ Key Partners } & \multicolumn{2}{|r|}{ Key Activities } & \multirow{2}{*}{\begin{tabular}{||l|l}
\multicolumn{2}{|c}{ Value Propositions } \\
1 & $\begin{array}{l}\text { Establish cooperative } \\
\text { relationships with state- } \\
\text { owned companies for } \\
\text { apprenticeship programs }\end{array}$ \\
\end{tabular}} & \multicolumn{2}{|r|}{ Customer Relationships } & Customer Segments \\
\hline 1 & $\begin{array}{l}\text { State-owned companies and private } \\
\text { companies engaged in the electricity sector }\end{array}$ & 1. & Educators who are competent in their fields & & 1 & Affordable tuition fees & $1 \mid$\begin{tabular}{l|l} 
High school \\
equivalent
\end{tabular} \\
\hline 2 & Media Partnership & $2 \mid$ & $\begin{array}{l}\text { Educators who are certification skill in their } \\
\text { fields }\end{array}$ & $2 \begin{array}{l}X Y Z \text { institute which } \\
\text { always prioritizes quality } \\
\text { first over quantity }\end{array}$ & 2 & $\begin{array}{l}\text { Have a lot of } \\
\text { scholarship programs } \\
\text { for students }\end{array}$ & \\
\hline 3 & High school equivalent located in Jakarta & 3 & $\begin{array}{l}\text { Experience to go directly into the field from } \\
\text { existing educators }\end{array}$ & $3 \begin{array}{l}\text { Affordable tuition fees } \\
\text { with various payment } \\
\text { methods }\end{array}$ & 3 & $\begin{array}{l}\text { Have solid cooperation } \\
\text { with state-owned } \\
\text { companies and other } \\
\text { private companies }\end{array}$ & \\
\hline & Cost Structure & & Key Resources & $4 \begin{array}{l}\text { The XYZ institute has a } \\
\text { comfortable place to } \\
\text { study and friendly staff }\end{array}$ & & Channels & \\
\hline 1 & Telephone, water, wi-fi and electricity costs & 1 & Privately owned land and building & & 1 & Social Media & \\
\hline 2 & Employee salary & 2 & Transportation & & & PT. PLN (Persero) & \\
\hline 3 & Office stationery costs & 3 & Laboratorium & & & & \\
\hline 4 & Advertisement costs & 4 & Meeting Room & & & & \\
\hline 5 & Fuel and Transportation costs & 5 & Sport Facilities & & & & \\
\hline \multirow{7}{*}{\multicolumn{2}{|c|}{\begin{tabular}{l|l|}
6 & Training costs \\
\end{tabular}}} & 6 & Place of worship & & & & \\
\hline & & 7 & Health Facilities & & & & \\
\hline & & 8 & Research Facilities & & & & \\
\hline & & 9 & Human Resources & & & & \\
\hline & & & Revenue Streams & & & & \\
\hline & & 1 & The foundation that houses the XYZ Institute & & & & \\
\hline & & 2 & Students & & & & \\
\hline
\end{tabular}

Figure 2 : Business Model Canvas Institute of XYZ 


\begin{tabular}{|c|c|c|c|c|}
\hline No & Strength & Weakness & Opportunity & Threats \\
\hline 1 & $\begin{array}{l}\text { Put quality over quantity first for all XYZ } \\
\text { Institute graduates }\end{array}$ & $\begin{array}{l}\text { Currently, XYZ Institute } \\
\text { does not have a branch } \\
\text { campus due to the recently } \\
\text { changed campus status }\end{array}$ & $\begin{array}{l}\text { A location in the middle of } \\
\text { an urban area }\end{array}$ & $\begin{array}{l}\text { The increasing } \\
\text { number of universities } \\
\text { in Jakarta made } \\
\text { competition } \\
\text { unavoidable }\end{array}$ \\
\hline 2 & $\begin{array}{l}\text { Qualified teaching staff in every } \\
\text { department }\end{array}$ & $\begin{array}{l}\text { There is still a lack of } \\
\text { training for employees or } \\
\text { lecturers to support their } \\
\text { performance }\end{array}$ & $\begin{array}{l}\text { Minimum graduate lecturers } \\
\text { from well-known campuses } \\
\text { make XYZ Institute have a } \\
\text { great opportunity to create } \\
\text { reliable graduates }\end{array}$ & $\begin{array}{l}\text { Increased competition } \\
\text { in the number of study } \\
\text { programs at several } \\
\text { universities }\end{array}$ \\
\hline 3 & $\begin{array}{l}\text { Teaching staff who are competent in their } \\
\text { respective fields according to their study } \\
\text { program }\end{array}$ & $\begin{array}{l}\text { There is still a lack of } \\
\text { facilities for students such } \\
\text { as floor plans and student } \\
\text { service information }\end{array}$ & $\begin{array}{l}\text { Apprenticeship program } \\
\text { with state-owned companies }\end{array}$ & $\begin{array}{l}\text { The occurrence of } \\
\text { competition in } \\
\text { facilities, quality and } \\
\text { administrative costs }\end{array}$ \\
\hline 4 & $\begin{array}{l}\text { Has a complete laboratory that always } \\
\text { supports the teaching and learning } \\
\text { process }\end{array}$ & & $\begin{array}{l}\text { Various scholarship } \\
\text { programs for students }\end{array}$ & $\begin{array}{l}\text { Decreasing number of } \\
\text { students due to the } \\
\text { increasing number of } \\
\text { choices for higher } \\
\text { education institutions }\end{array}$ \\
\hline 5 & $\begin{array}{l}\text { The facilities that are always developing } \\
\text { every year not only facilities for teaching } \\
\text { staff but also for students }\end{array}$ & & & \\
\hline 6 & $\begin{array}{l}\text { Cooperation with various companies in } \\
\text { the field of Energy and Electricity such as } \\
\text { PT. PLN, Indonesia Power, PJB, } \\
\text { Telkom, ESDM, etc. }\end{array}$ & & & \\
\hline
\end{tabular}

Figure 3: XYZ Institute's SWOT Analysis

\section{RESULTS AND DISCUSSION}

\section{Identify the Nine Elements of a Business Model Canvas Using SWOT \\ Customer Segment}

The strength factor (strength) in this element was demonstrated by the XYZ Institute which has a collaborative program with several state-owned and private companies in the energy and electricity sectors such as PT. PLN, Indonesia Power, PJB, Telkom, Ministry of Energy and Mineral Resources, and others. And this XYZ Institute also always prioritizes the quality of its graduates compared to its quantity. The target market is high school or equivalent students in West Jakarta and throughout Indonesia who have worked with PT. PLN. Threats factor which is seen from the ability of competitors who are relatively superior, as well as the increasing number of competitors that appear in the area around the XYZ Institute. Judging from the Opportunities factor owned by the XYZ Institute,

\section{Value Proposition}

The element of value propositions, demonstrating the strength of the offered values has become the XYZ Institute's brand identity and integrity, because every teaching staff has been given a lot of training in accordance with their educational background to be applied to their students. Always prioritize quality over quantity and affordable tuition fees. The weakness that arises is the lack of training held for non-educators so as to create an imbalance in working within a company. Factors threats in this element are the ability of competitors to manage the same value. As for the opportunity factors, there are very many high school and equivalent schools in West Jakarta and the change in name and status of the university itself.

\section{Channels}


The information channel that has been used so far is through social media which can be a force to promote the XYZ Institute to the wider community. Optimization of promotions through social media is still a weakness because it relies too much on promotions which are sometimes not always on target. Even this weakness can also be a threat because with many other private universities present by way of promotion through social media as well. However, the opportunity offered is that with this media, it can increase the number of students who register at the XYZ Institute.

\section{Customer Relationship}

Factor strength in this element is the ability of the XYZ Institute which has a collaboration program for internships or job search for students and alumni of the XYZ Institute in various BUMN and private companies. Renewal of laboratory facilities for students, as well as scholarship programs provided by the Institute. Factor weakness is shown by the absence of branch campuses, currently the Institute is only in West Jakarta and there are no plans for construction of a new campus building. But the opportunities that exist today, with a strategic campus location that is in an environment that is not a small population, is very possible to attract many new students. The threat is, if the surrounding universities are able to manage this element better than the XYZ Institute.

\section{Key Activites}

Strength factors in this element are shown from a number of qualified and competent educators in their respective fields in accordance with the study program, educators who also have various kinds of certifications and experience to jump right into the workforce. The analysis of the threat factor is the increased competition in the world of Higher Education in West Jakarta which is able to provide a much more competent educator. Opportunity in this element is that more and more companies are offering collaboration with the XYZ Institute to make this Higher Education better known to companies and the wider community.

\section{Key Resource}

Strength factor analysis in this element can be identified through the availability of training for Educators and students alike, the availability of complete laboratories for all majors, as well as the expertise and experience of excellent teaching staff and also their own Land and Buildings. However, weakness factors also arise from infrastructure such as laboratory facilities and classrooms that need to be rejuvenated and standardized in human resources. Factor threats that exist in this element are more to the completeness of the tools that exist in each laboratory and HR based on certification / educational background. Opportunity for the XYZ Institute of Technology is the development of the Institute in terms of collaboration currently being established with many companies and other tertiary institutions.

\section{Key Partnership}

Factor strengths in this element are shown by the ability of the XYZ Institute to hold seminar events that bring in speakers in accordance with their fields of expertise and highly educational material and also establish good relationships with companies that collaborate with the Institute by providing the best graduates of the XYZ Institute, as well as support from several media partnerships. Weakness in this element is the weak internal capability in the relevant part in handling clients. Thretas factor is the ability of competitors to manage their partners well. Factor opportunity in this element can be seen from the opportunity to be able to work together in addition to the company but also with other senior high schools / equivalents to attract more students. 


\section{Cost Structure}

Factor strength in this element, is that Institiut XYZ has financing in the form of fixed costs with variable costs that can be predicted in advance. Electricity, telephone and water rental fees. The weakness factor is the lack of optimal resources to manage it, this can be a threat as well because many competitors are feared to be better able to manage it. While the opportunity factor is that many companies have collaborated with the XYZ Institute so that they can reduce production costs.

\section{Revenue Stream}

Financial assistance from the Foundation that houses the XYZ Institute is a force in this element. weakness in this element is the new marketing is able to reach the target of $80 \%$ of the number of targets that enter the XYZ Institute. Meanwhile, marketing competitors who are more innovative and creative are feared to be a threat to the XYZ Institute. Changing the current status of the Institute can be seen as a new opportunity to increase revenue in the future.

\section{CONCLUSIONS AND RECOMMENDATIONS}

Based on the identification that has been carried out by researchers of the XYZ Institute, it is known that the Institute has not taken full account of the changes in the surrounding competitive environment. And also the rejuvenation of facilities in the Institute that need to be considered in order to be able to compete with other competitors. The absence of branch campuses has hampered the growth of the Institute's brand image. But despite the absence of a branch campus, the Institute is capable enough to produce graduates who are ready to work according to their fields. Collaboration with stateowned companies or other private companies for the internship program and alumni distribution.

In this research, the suggestions that researchers can convey are, it is necessary to conduct comparative study activities to other tertiary institutions to be able to adapt the system that they apply. Rejuvenation of the existing facilities really needs to be improved considering that this facility can be an attraction for prospective students who will enter the XYZ Institute. Further research is needed to improve the quality of the XYZ Institute.

\section{REFERENCES}

Royan, FM (2014). Distributor canvas business model: Mapping the distributor's optimal performance and 30 mistakes made. Jakarta: PT Gramedia Pustaka Utama.

Moleong, LJ (2010). Qualitative research methodology. Bandung: PT Youth Rosdakarya.

Osterwalder, A., Pigneur, Y. (2010). Business model generation. Jakarta: Elex Media Komputindo.

Hapzi, Ali (2020). Strategic Management. Canvas Business Model, Diversification and Balanced Scorecard. Jakarta

Jessica, Nita., Indriyani, Ratih (2017). Business Canvas Analysis on Tirotti Bakery. AGORA.

Florencia, B. (2015). Business Model Canvas on CV Sekawan Cosmetics Sidoarjo. AGORA, 207-214.

Wiyawati, Rahma., Purwanto, Idris (2019). Designing a Business Model Based on the Business Model Canvas on Radio MQFM Jogja. Pro Business Journal Vol. 12 (2), 33-46

Sudarwanto, Wiwik., Tikwalau Erlando Desta. (2014) Factors that influence high school / vocational school students on the decision to choose a private tertiary institution 